\title{
The evolution of construction waste sorting on-site
}

\author{
Hongping Yuan ${ }^{1 *}$, Weisheng $\mathrm{Lu}^{2}$, Jane Jianli Hao ${ }^{3}$
}

\section{Dr. Hongping Yuan (* corresponding author)}

Associate Professor

School of Economics and Management, Southwest Jiaotong University, Sichuan, 610031

China

Email: hpyuan2005@gmail.com

\section{Dr. Weisheng Lu}

Assistant Professor

Department of Real Estate and Construction, University of Hong Kong, Hong Kong

\section{Dr. Jane Jianli Hao}

Associate Professor

Department of Architectural Science, Ryerson University, Canada 


\section{Abstract}

Construction waste comprises inert (e.g. sand, bricks, and concrete) and non-inert materials (e.g. bamboo, plastics, glass, wood, and paper). In Hong Kong, the inert portion can be deposited at public filling areas for land reclamation while the non-inert portion is disposed of at landfills. However, construction waste is usually a mixture of both inert and non-inert materials and thus a segregation of the two portions is of paramount importance for effective waste minimization. Previous studies have revealed that construction contractors in Hong Kong were unwilling to carry out on-site construction waste sorting (CWS) even though it has numerous advantages. After a decade, the situation should have changed, particularly given the promulgation of a waste charging scheme in 2006 imposing levies on different methods of construction waste disposal. This study thus aims at ascertaining the state-of-the-art on-site CWS practices in Hong Kong, with a particular interest in its evolution over the past ten years. Data was collected through case studies of six construction sites where a hybrid research method included a literature review, non-participant observations, and interviews. It was found that construction waste management (CWM) regulations have significantly enhanced on-site CWS in Hong Kong. Site space and project stakeholders' attitudes are still regarded as the most critical factors but labor and cost are no longer of major concerns in undertaking onsite CWS. Instead, a market for recyclables and an awareness of the profound environmental benefits are now perceived as being of major importance in these practices. Findings from the study can be used to review the effectiveness of current on-site CWS in Hong Kong, and through benchmarking they can also be used to develop good CWS practices in other economies.

\section{Keywords}

Construction waste, on-site, waste sorting, case study 


\section{Introduction}

Construction waste is a major concern in Hong Kong. Construction activities in the region unavoidably produce a great amount of construction waste. Latest statistics from the Hong Kong Environment Protection Department (HKEPD) (2010) showed that in 2010 construction waste accounted for $25.9 \%$ of all the solid waste generated in Hong Kong, reaching 3,584 tonnes per day (tpd) disposal at landfills. However, burying the large amount of construction waste in landfills leads to an extensive volume of air, water, and soil pollution due to the production of $\mathrm{CO}_{2}$ and methane from anaerobic degradation of the material. In addition to the adverse environmental impacts, construction waste also brings tremendous pressure to the limited landfill space in this extremely compact city. The HKEPD (2007) predicted that with an estimated $24 \%$ annual increase in construction waste disposal, the landfill facilities in Hong Kong would be full by 2017. Cheung (2010) stated that landfill "should be treated as a precious asset and not for daily use”. Therefore, there is an acute need to effectively manage construction waste in Hong Kong so as to reduce its negative impact on the environment.

In Hong Kong, construction waste is categorized into inert and non-inert, where the inert materials, comprising mainly sand, bricks and concrete, is deposited at public filling areas for land reclamation, while the non-inert portion, consisting of materials such as bamboo, plastics, glass, wood, paper, vegetation and other organic materials, is disposed of at landfills as solid waste. However, construction waste is usually a mixture of both inert and non-inert materials and although segregation of the two types of waste is of paramount importance (Wang et al., 2010), the nature of the materials makes them difficult to sort. Poon et al. (2001) found out that construction contractors were reluctant to carry out on-site waste sorting owing to various difficulties in spite of the perceived advantages of doing so. Later, with the aid of a flow-free 
mapping presentation technique, Shen et al. (2004) developed a construction waste management mapping model (WMMM). The WMMM was rather intuitive in facilitating descriptions of CWM procedures on site with a view to comparing CWM practices between different construction sites, and thus identifying both good practices and weak areas. The two studies were both undertaken with an attempt to enhance the effectiveness of on-site CWS/CWM activities in the context of Hong Kong.

Over the past decade, a series of CWM regulations have been issued in Hong Kong. These primarily include adopting a waste disposal ordinance, launching an off-site CWS program, commissioning a pilot concrete recycling plant, implementing the waste management plan, promoting a waste disposal charging scheme, and implementing a trip-ticket system (Tam, 2008). Among them, three regulations, namely, the waste disposal charging scheme, the offsite CWS program, and the trip-ticket system, are closely related to CWS practices. In this connection and taking the research by Poon et al. (2001) as the point of departure, two questions that arose were (a) what is the status quo of on-site CWS in Hong Kong? and (b) to what extent have on-site CWS practices changed?

The primary aim of the study was twofold. Firstly, to ascertain the current state-of-the-art onsite CWS practices in Hong Kong. Secondly, to conduct a comparison between the practices identified and the on-site CWS practices between 2002 and 2012. The institutional settings for on-site CWS was juxtaposed with those 10 years ago to allow a contrasting lens through which the evolution of on-site CWS practices in Hong Kong can be viewed. It was anticipated that the findings would be very useful for longitudinally analyzing on-site CWS practices in Hong Kong and may also be applicable to other economies that are committed to construction waste management. The paper is organized as follows. Firstly, a literature review regarding 
on-site CWS is conducted to understand the rationale and major hurdles of carrying out onsite CWS by putting it into the Hong Kong context. Secondly, the research methodology adopted is introduced, which comprises a hybrid research strategy that involves a literature review, non-participant observations, and interviews with personnel employed on six construction projects. Thirdly, a case study was carried out and detailed analyses and discussions presented. Finally the paper concludes by recommending institutional arrangements for encouraging better on-site CWS by connecting it with the whole waste management system in Hong Kong.

\section{On-site construction waste sorting in Hong Kong}

Construction waste is defined as "any substance, matter or thing which is generated as a result of construction work and abandoned whether or not it has been processed or stockpiled before being abandoned” (HKEPD, 2010). It is a mixture of surplus materials arising from site clearance, excavation, construction, refurbishment, renovation, demolition and road works (HKEPD, 2010). To understand the rationale of advocating on-site CWS, it is better to understand the character of construction waste first. Although it is often included as one of the forms of municipal solid waste (MSW), construction waste is considered as heterogeneous by comparison with general MSW (e.g. household waste) or other industrial waste (e.g. hospital waste and electrical waste) (Lu and Yuan, 2011). Construction waste comprises inert (e.g. sand, bricks, and concrete) and non-inert materials (e.g. bamboo, plastics, glass, wood, and paper). As mentioned previously, in Hong Kong, the inert portion of construction waste can be accepted by public fill reception facilities, while the non-inert part is dumped at landfills. It is thus sensible to sort the construction waste into inert and non-inert parts instead of burying them together in landfills. This is particularly important for compact areas such as Hong Kong 
where land reclamation is increasingly rare and existing landfills will be full in the very near future.

Over the last ten years, the Hong Kong government has made a considerable effort to manage the large amounts of construction waste. Three regulations have been issued to improve onsite CWS in Hong Kong. Notably, a waste disposal charging scheme (WDCS) was implemented based on the 'polluter pays principal' in 2006. According to the scheme, a construction contractor will have a levy of HK\$125 (US\$1 = HK\$7.76) imposed for every tonne of construction waste containing not more than $50 \%$ by weight of inert substances it disposes of at landfills; it will be levied HK\$100 per tonne if the generated construction waste containing more than $50 \%$ by weight of inert substances is accepted by off-site sorting facilities; while it will be charged only HK\$27 per tonne if the construction waste consisting entirely of inert materials is accepted by public fill reception facilities. The discriminative prices are set up based on the premise that different forms of construction waste will have different degrees of impacts on the environment and society, and thus should be charged differently to encourage the minimization of construction waste.

Another significant endeavor is an off-site CWS program launched in 2006. Meanwhile, two off-site CWS facilities were set up in line with the implementation of the WDCS. According to the statistics provided by the Hong Kong Civil Engineering and Development Department (CEDD), the off-site CWS facilities have successfully handled a total of 5.11 million tonnes of construction waste by February 2012. A recent study also revealed that the off-site CWS programs is effective in that it not only separates construction waste off-site but also encourages construction contractors to do on-site CWS (Lu and Yuan, 2012). 
It seems that a rigid definition of on-site waste sorting is absent in the literature. Generally, people treat it as a good practice whereby construction waste is separated on construction sites and sorted into different groups in line with its characteristics and components. Through this, some valuable components can be picked up for reuse and recycle. For example, Poon et al. (2001) and Wang et al. (2010) found that on-site CWS could increase the rates of construction waste reuse and recycling, and reduce the costs for construction waste transportation and disposal. However, Poon et al. (2001) reported that construction contractors in Hong Kong were mostly unwilling to conduct on-site CWS for a variety of reasons. Through investigating the feasibility of three on-site CWS alternatives, it was revealed that factors such as limited site space, management efforts, labor and cost, and interference with normal site activities were the main constraints of on-site CWS in Hong Kong (Poon, 2001). The unpopularity of on-site CWS can be further exacerbated by other factors such as waste sortability, immature market for trading recyclables, lack of standard practices, and probably most significantly, major project stakeholders' negative attitudes toward on-site CWS (Wang et al., 2010). A study by Shen et al. (2004) presented a WMMM through mapping the on-site CWS processes of six real-life construction projects in Hong Kong, drawing on which on-site CWS can be optimized and the effectiveness of the practice improved.

Despite studies providing good references for understand on-site CWS in Hong Kong, a more in-depth comprehensive understanding is required. The present practices might be significantly different from those reported by Poon et al. (2001) and Shen et al. (2004) owing to the elapse of the time and in particular to the overall influence of the on-site CWS regulations. This was the rationale for the research questions.

\section{Research methodology}


By pondering the strengths and weaknesses of the research methodologies applied in previous studies (e.g. Shen et al. 2004; Poon et al. 2001), this research adopted a hybrid research strategy involving literature review, pilot study, case study, non-participant observations, and interviews. The entire research process is depicted in the flowchart shown as Figure 1.

\section{[Please insert Figure 1 here.]}

In Step 1, a thorough examination on related literature and government reports/regulations was carried out in order to obtain a comprehensive understanding of the on-site CWS practices in Hong Kong, based on which the research questions were formulated.

Following with Step 2, a site visit was conducted at one of the two off-site CWS facilities located in the Tuen Mun area of Hong Kong. The purpose of the site visit was to pilot the research questions and familiarize all research members with the nature of construction waste components and CWM problems on-site, which was also preparation for the case studies.

In Step 3, six case studies were conducted. The information of the six cases is summarized in Table 1. It can be seen that five of the surveyed construction projects are new building construction, while the rest are infrastructure projects. It was expected that construction waste generated from infrastructure projects would be quite different from that produced by new building construction projects. Also public projects such as those launched by Hong Kong Housing Authority (HKHA) (e.g. public housing) and the Architecture Services Department (ASD) (e.g. schools, offices, and other institutional buildings) are subjected to public scrutiny and thus their on-site CWS practices should be largely different from private projects. Two major tasks were performed in each case to collect research data for answering the research 
questions. One task involved a set of non-participant observations in each of the surveyed construction sites, which were carried out by three research assistants. A waste manager accompanied the observers and answered the following questions that they raised:

(a) what are the typical on-site CWS methods in Hong Kong?

(b) what are the typical on-site CWS methods adopted in the project under investigation?

(c) what are the major benefits of conducting on-site CWS?

(d) what are the major costs in implementing on-site CWS? and

(e) what are the major barriers to carrying out on-site CWS in Hong Kong?

During the observations, notes were carefully taken to record the key path showing how the construction waste goes through from its generation to site separation. The observers used the free-flow mapping presentation technique (WMMM) devised by Shen et al (2004) to sketch the on-site CWS process as they observed it. Other graphic tools or keywords were also adopted as necessary.

\section{[Please insert Table 1 here.]}

Another task in step 3 was to conduct face-to-face interviews with project personnel who were responsible for CWM on-site. The interviews not only provided a deeper understanding of on-site CWS practices, but also provided useful information about major factors affecting on-site CWS in Hong Kong. The same survey processes were repeated in each of the six construction projects. In four surveyed construction projects, it is the safety manager that is responsible for on-site CWM issues, while the environmental officer is assigned to be in charge of managing construction waste on sites in the other two projects. Most of the interviewees were familiar with CWM as they had more than 3 years working experience in managing construction waste. 
Back at the research desk the data was carefully processed and analyzed. Given that the data was mainly qualitative and descriptive, content analysis was conducted. The method of content analysis used was a systematic, replicable technique for compressing many words of text into fewer content categories based on explicit rules of coding (Stemler, 2001), which enabled the inclusion of large amounts of textual information and systematically identified its properties. The analysis involved human comparison of the on-site CWS practices with the ones reported by Poon et al. (2001) and Shen et al. (2004). To reduce potential bias, the coding process was conducted by two researchers who needed to agree on the content code of each item. The detailed data analyses are described in the following section.

\section{Analyses, discussions, and findings}

\section{1 On-site CWS processes}

Drawing on the analytic results of the six cases, an intuitive and lucid diagram as shown in Figure 2 was formulated for analyzing and depicting on-site CWS processes. Although this diagram cannot reflect every detail of on-site CWS in each of the cases, it does represent the most critical and generic processes involved in real-life projects.

\section{[Please insert Figure 2 here.]}

First and foremost, according to the regulations, a waste management plan or project environmental management plan must be developed for each government project before the commencement of building work. On-site CWS will be carried out by largely following the plan. Tam et al (2008) have reported the usefulness of such a plan. 
Once construction waste is generated, source separation will be conducted by workers to prevent waste materials being mixed. Basically, there are four clusters of waste on construction sites: (a) domestic waste, (b) inert construction waste, (c) non-inert construction waste, and (d) chemical waste. Since it is generated during the building work, the waste should be managed properly in the first instance so as not to interfere with the normal construction process. Specific on-site sorting practices vary from one project type to another, depending on the different mixture of waste. For example, as little non-inert construction waste is generated from infrastructure projects, waste management plans mainly deal with earth and mud. On-site waste sorting is thus rarely recorded on infrastructure projects.

For cluster (a) waste, domestic waste such as paper, plastic and aluminum bottles is required to be dumped in designated recycling bins, which are normally placed at specific zones around the site (see Figure 3-a). Traditionally, domestic waste is not included as a part of construction waste, but the observations in this study show that there was a significant amount of domestic waste in each of the cases studied. This was supported by an interviewee in infrastructure 'Project A' who informed the interviewer that the domestic waste generated by the project was about 10 trucks per month (given that the volume of a truck is around $6 \mathrm{~m}^{3}$, this translates to $60 \mathrm{~m}^{3}$ of domestic waste per month). Other interviewees claimed that construction activities could be seriously disrupted if domestic waste was not carefully handled.

With regard to cluster (b) waste, the inert construction waste generated is collected and transported to a designated area on the ground floor of construction sites after some preliminary source separation is completed on each floor. Normally the inert construction waste is transported to the ground floor by material hoist or refuse chute (see Figure 3-b). 
After that, reusable inert construction waste can be sorted for further use, while non-reusable inert construction waste will be either sent to off-site CWS facilities for further separation or transported to public fill reception facilities for final disposal.

Cluster (c) waste, non-inert construction waste, is also collected and transported to specific large containers placed on the ground floor of construction sites after source separation is carried out. For the non-inert waste generated in higher floors, it is handled and transported to the ground by refuse chutes or cranes in most of the cases. Following this, the non-inert construction waste can be categorized into three groups (i.e. reusable, vendible and nonreusable) according to its characteristics. Each type of reusable non-inert construction material will be grouped and stored in a separate container (see Figure 3-c) for later use in construction projects. Vendible non-inert materials (such as metallic material) can be sold to recycling companies and the remainder will be disposed of at landfills.

In order to ensure that cluster (d) waste, chemical waste, is properly managed, strict regulations have been promulgated by the HKEPD to control them from the source of production through to the place of final disposal. In the surveyed cases, all hazardous construction materials are required to be collected and placed in designated zones or labeled tanks (see Figure 3-d). Construction contractors have to employ licensed companies, who are registered with the HKEPD, to handle such waste. A schematic diagram showing the procedure of chemical waste handling is provided in Figure 4. It is apparent that all major processes in chemical waste handling and disposal are strictly controlled and enforced by the HKEPD. Contractors are required to pay extra for chemical waste treatment and disposal.

\section{[Please insert Figure 3 here.]}




\section{[Please insert Figure 4 here.]}

By comparing the observed on-site CWS processes demonstrated in Figure 2 with those identified by Shen et al. (2004), significant differences were identified. For example, when Shen et al. (2004) conducted their investigation there was no waste management plan or project environmental management plan in place before building work commenced. However, in each of the studied cases, such a plan had been developed to specify major construction waste management methods that would be used to minimize construction waste, as well as main construction waste minimization targets that should be fulfilled. These notable differences may be largely due to the Hong Kong government's initiatives in the past few years to improve on-site CWS.

In the study by Shen et al. (2004), several major weaknesses of on-site CWS practices in Hong Kong were presented and discussed, including: (W1) lack of waste sorting-out process, (W2) no consideration for recycling waste, (W3) intensive labor work involved in handling waste, (W4) double-handling in collecting waste, and (W5) time consumed for collecting waste from scattered collection locations. They further pointed out that these weaknesses needed to be addressed for promoting the effectiveness of on-site CWM in Hong Kong. In the

present study, the shortcomings of on-site CWM practices in Hong Kong as identified by Shen et al. (2004) are examined by comparing 'past' and 'present' practices. The results are tabulated in Table 2.

\section{[Please insert Table 2 here.]}


Findings from the six case studies demonstrate that all five weaknesses (W1 to W5 above) identified by Shen et al. (2004) are no longer significant in Hong Kong. Specifically, in the cases studied construction waste is separated at source and waste recycling measures are adopted to recycle all construction waste generated on site. Different types of waste, i.e. domestic waste, inert and non-inert construction waste, and chemical waste are collected and dumped in different designated areas/facilities on the construction site, which can largely prevent double-handling and save waste collection time. Also, in each one of the projects, rather than designating a particular person to be responsible, all the workers are expected to separate and place generated construction waste appropriately in line with the waste management plan. Instead of being perceived as interrupting the construction process, waste sorting has been increasingly recognized as an integral part of regular construction activities in Hong Kong.

\subsection{Factors affecting on-site CWS}

Poon et al. (2001) identified factors potentially constraining on-site CWS practices in Hong Kong, which encompass (F1) site space, (F2) management effort, (F3) labor and cost, (F4) interference with normal site activities, (F5) waste sortability, (F6) market for recyclables and environmental benefit, and (F7) project stakeholders' attitudes toward implementing on-site CWS. To better understand the evolution of Hong Kong's on-site CWS practices during the last decade, a comparison of the constraints between those reported in Poon et al. (2001)'s study and the outcomes from our case studies was performed and is presented in Table 3.

\section{[Please insert Table 3 here.]}


The table referred above shows that all interviewees in this study perceived compact site space as the major factor affecting on-site CWS; this is the same perception that Poon et al. (2001) reported eleven years ago and is unlikely to change in the foreseeable future. As less than 25\% of Hong Kong's 1,000 sq km hilly terrain is developed to accommodate 7 million people, construction sites are often located in very crowded neighborhoods. This means that sites are often very small forcing contractors to carefully plan the site layout and the construction processes with the consequence that on-site waste sorting, which occupies a considerable amount of much-needed space, is too often marginalized. This to a certain extent explains the necessity for the off-site CWS program; if it is difficult to sort the waste on-site, sort it off-site.

By comparing the results obtained in the case studies with those revealed by Poon et al. (2001), it is clear that management effort (F2) and project stakeholders' attitudes (F7) toward implementing on-site CWS are consistently perceived as the most critical factors affecting onsite CWS in Hong Kong. Dealing with construction waste not only places demands upon environmental engineers but also upon the main contractor's management team. Workers and site managers must be empowered by senior management in order to achieve successful waste management. Nowadays, both practitioners and researchers are aware that in order to achieve waste management success, the roles that the main contractor can play should be expanded to all the stakeholders. Stakeholders have different interests in and impacts on a system, either positively or negatively (Freeman, 1984). Successful CWM requires the joint effort of all stakeholders (Hao et al., 2007; and Tam, 2008). This concept was highlighted in the Rio de Janeiro Declaration in the UN Conference on Environment and Development (UNCED, 1992), and endorsed by the case study interviewees. 
Interestingly, the interviewees in the case studies largely reflected that (F3) labor and cost is no longer a major concern in conducting on-site CWS. This is significantly different from what Poon et al. (2001) reported some 10 years ago. The following quote from an interviewee working on Project C provides a reasonable justification for this: “cost and labor comes to the least decisive factor in affecting on-site CWS mainly because waste sorting in the project is done by all workers but no specialized labor is assigned for this task". As reported above, immediately after the construction waste is generated, source separation will be conducted by workers to prevent waste materials being mixed.

However, as can be seen from the responses to F4 (Table 3), interviewees seem to feel that they are caught in paradoxical situation. On the one hand they welcome the practice of construction waste being sorted consciously by the workers once a trade is finished, while on the other hand they are concerned that on-site CWS interrupts normal site activities and slows progress. The later is a particular concern in Hong Kong where efficiency is a mantra and the construction process is conducted at a very fast pace. Encouragingly though, there is an increasing acceptance that the time spent on waste management should not be seen as a time consuming nuisance but rather an important necessity. Contributing to the acceptance of conducting on-site WCS has undoubtedly been the levies imposed by the WDCS and an increasing awareness of environmental issues generally. The Construction Industry Council (HKCIC) has also helped by enforcing a site housekeeping scheme that requires the worksite, including the construction waste thereon, to be well organized at all times. Consequently, waste sorting is fast becoming an integral part of regular construction activities in Hong Kong.

According to Poon et al. (2001), waste sortability (F5) and a market for recyclables and environmental benefit (F6) were regarded as having a minor influence on on-site CWS. 
However, as found in the case studies conducted 10 years later, most interviewees argued that these factors are critical in that construction waste recycling and trading are getting more difficult due to there being insufficient recycling traders, especially for timber materials. This is probably because the construction market is shrinking in Hong Kong, and as such, contractors find it more difficult to find other projects on which to reuse inert materials for such things as site formation and timber formwork. The longitudinal comparison in this study also reveals that environmental considerations have become more and more important when implementing construction projects in Hong Kong, which has given legitimacy to on-site CWS in the region.

\subsection{Effects of policies on on-site CWS in Hong Kong}

Policies are often at the core of the rationales that have led to changes in on-site CWS in Hong Kong. As mentioned previously, three CWM regulations, namely, (R1) the waste disposal charging scheme (WDCS), (R2) the off-site CWS program, and (R3) the trip-ticket system, are particularly relevant to on-site CWS in Hong Kong. Together with other policies, they form an interlocking CWM system that pushes on-site CWS practices forward in Hong Kong.

Interviewees in Projects A and B reflected that their on-site CWS activities were greatly affected after the implementation of the WDCS and the trip-tick system. Before 2004 they only separated construction materials from the on-site waste that could be reused or sold. But currently, more careful construction waste separation has to be carried out on-site so that waste materials with different characteristics can be handled and disposed of in different facilities such as the off-site CWS facilities, public fill reception facilities, and landfills. As previously mentioned, when waste is accepted at off-site CWS facilities the construction 
contractor is only charged HK\$100 per tonne, HK\$25D less than at landfills. However, Lu and Yuan (2012) reported that the facilities have strict criteria on the type of waste that they will accept. A typical example is that in Project F, there is a system monitoring the loading of dumping trucks when the trucks reach the weighing bridge. According an interviewee from the project, this could prevent the trucks from overloading and consequently being rejected by off-site CWS facilities. Also, the construction waste sent to off-site CWS facilities has to be sorted carefully to ensure that it does not contain significant amounts of domestic waste or non-inert materials. Once the construction waste is rejected and sent back to the construction site, the construction contractor has to spend about HK\$700 on transportation.

With the enactment of the trip-ticket system, the destinations as well as the transportation route of construction waste generated by a particular construction project can be easily tracked and monitored so that it is almost impossible for the transporter to dump the waste in an unauthorized area. An interviewee from Project E pointed out that since implementation of the trip-ticket system, the number of cases in Hong Kong of construction waste being illegally dumped sharply decreased.

Perhaps more profoundly, all interviewees stressed that in recent years vocational training has to be given to all workers to educate them on how to carry out on-site CWS effectively. As commendable as this is, a mandatory certification scheme for on-site construction waste sorting, similar to the 'Green Card' system for construction safety in Hong Kong, would be the next logical step. Interviewees from Projects B and F reflected that their workers are rewarded for their good on-site CWS practices, which has been an effective incentive to encourage better on-site CWS performance. The same interviewees also claimed that on-site 
CWS activities in their projects have be better arranged and performed since the launch of vocational training and the 'reward for environment' program.

\section{Conclusions}

By conducting six case studies, the status quo of on-site CWS practices in Hong Kong has been thoroughly investigated. In particular the study has shown that the following five primary weaknesses presented by Shen et al. (2004) have been effectively addressed over the past decade: (W1) lack of waste sorting-out process, (W2) no consideration for recycling wastes, (W3) intensive labor work involved in handling wastes, (W4) double-handling in collecting wastes, and (W5) time consumed for collecting waste from scattered collection locations. Various management measures have been adopted to address the weaknesses, such as requiring construction contractors to develop a waste management plan or environmental management plan before the commencement of building works, and by requiring containers to be placed on site to collect and store construction waste.

The comparison between current on-site CWS practices with those reported by Poon et al. (2001) reveals some similarities and some differences. Compact site space remains a critical factor that constrains on-site CWS practices, a situation that is unlikely to change in the foreseeable future. And, management efforts and project stakeholders' attitudes toward implementing on-site CWS are still regarded as the most critical factors affecting on-site CWS in Hong Kong. However, labor and cost are no longer of major importance in influencing on-site CWS, and project teams tend to treat on-site CWS as an integral part of the construction process instead of a cause of work disruption. Further, project managers see that an increasing market for recyclables will incentivize on-site CWS practices in a broad 
social context where environmental considerations are not disconnected from construction activities.

Based upon the comparisons, it can be concluded that on-site CWS practices in Hong Kong have been effectively enhanced over the past decade. A direct contribution of the improvement of on-site CWS is that more construction materials are separated at source, and thereby resource reuse and recycling efficiency has been greatly increased. Better on-site CWS has also resulted in less construction waste going to landfills. In short, the negative impact of construction activities on the environment has been significantly reduced through conducting on-site CWS. Findings from this study provide a better understanding of the latest practices of on-site CWS in Hong Kong by having juxtaposed 'past' and 'present' practices. Through benchmarking, the findings may also be useful for developing 'good CWS practices' in other economies that are committed to construction waste management.

\section{Acknowledgements}

The research was supported by the Hong Kong Research Grants Council (RGC) Public Policy Research (PPR) Scheme (RGC Ref. HKU7016-PPR-11). Thanks are due to Dr. Yu Zhang, Ms. Julie Kwan, and Mr. Ivan Hui for their assistance in this research.

\section{References}

Cheung, C.F. (2010). Refuse Mountain Makes HK Most Wasteful Place in World. South China Morning Post, Oct. 26, 2010.

Freeman, E. (1984), Strategic Management: A Stakeholder Approach, Pitman, Boston, MA. 
Hao, J.L., Hills, M.J., and Huang, T. (2007), A simulation model using system dynamic method for construction and demolition waste management in Hong Kong, Construction Innovation, 7(1), 7-21.

HKDB (Hong Kong Development Bureau). (2010). Trip Ticket System for Disposal of Construction and Demolition Materials. Available at: http://www.devb.gov.hk/filemanager/technicalcirculars/en/upload/308/1/C-2010-0601.pdf.

HKEPD (Hong Kong Environmental Protection Department). (2010). Monitoring Solid Waste in Hong Kong: Waste Statistics for 2010. Available at: < https://www.wastereduction.gov.hk/en/materials/info/msw2010.pdf>.

HKEPD (Hong Kong Environmental Protection Department). (2007). Monitoring Solid Waste in Hong Kong: Waste Statistics for 2010. Available at: < https://www.wastereduction.gov.hk/en/materials/info/msw2007.pdf>.

HKEPD. (2012). Waste: Problems and Solutions. Available at: < http://www.epd.gov.hk/epd/english/environmentinhk/waste/prob_solutions/chemical_wmi nhk_p.html >.

Lu, W.S and Yuan, H.P. (2011). A framework for understanding construction and demolition waste management studies. Waste Management, 31(6), 1252-1260.

Lu, W.S. and Yuan, H.P. (2012). Off-site sorting of construction waste: what can we learn from Hong Kong?. Resources, Conservation and Recycling, Under review.

Poon, C.S., Yu, A.T.W., and Ng, L.H. (2001). On-site sorting of construction and demolition waste in Hong Kong. Resources, Conservation and Recycling, 32(2), 157-172.

Stemler, S. (2001). An overview of content analysis. Practical Assessment, Research \& Evaluation, 7(17), 1-8. 
Shen, L.Y., Tam, V.W.Y, Tam, C.M., and Drew, D. (2004). Mapping approach for examining waste management on construction sites. Journal of Construction Engineering and Management, 130(4), 472-481.

Tam, V.W.Y. (2008). On the effectiveness of implementing a waste management plan method in construction. Waste Management, 28(6), 1072-1080.

United Nations Conference on Environment and Development (UNCED) (1992), Report of the United Nations Conference on Environment and Development, Rio de Janeiro. UNCED, chapter. 21, New York.

Wang, J.Y., Yuan, H.P., Kang, X.P., and Lu, W.S. (2010). Critical success factors for on-site sorting of construction waste: a China study. Resources, Conservation and Recycling, 54(11), 931-936.

Yuan H.P. and Shen, L.Y. (2011). The research trend of construction and demolition waste management. Waste Management, 31(4), 670-679. 


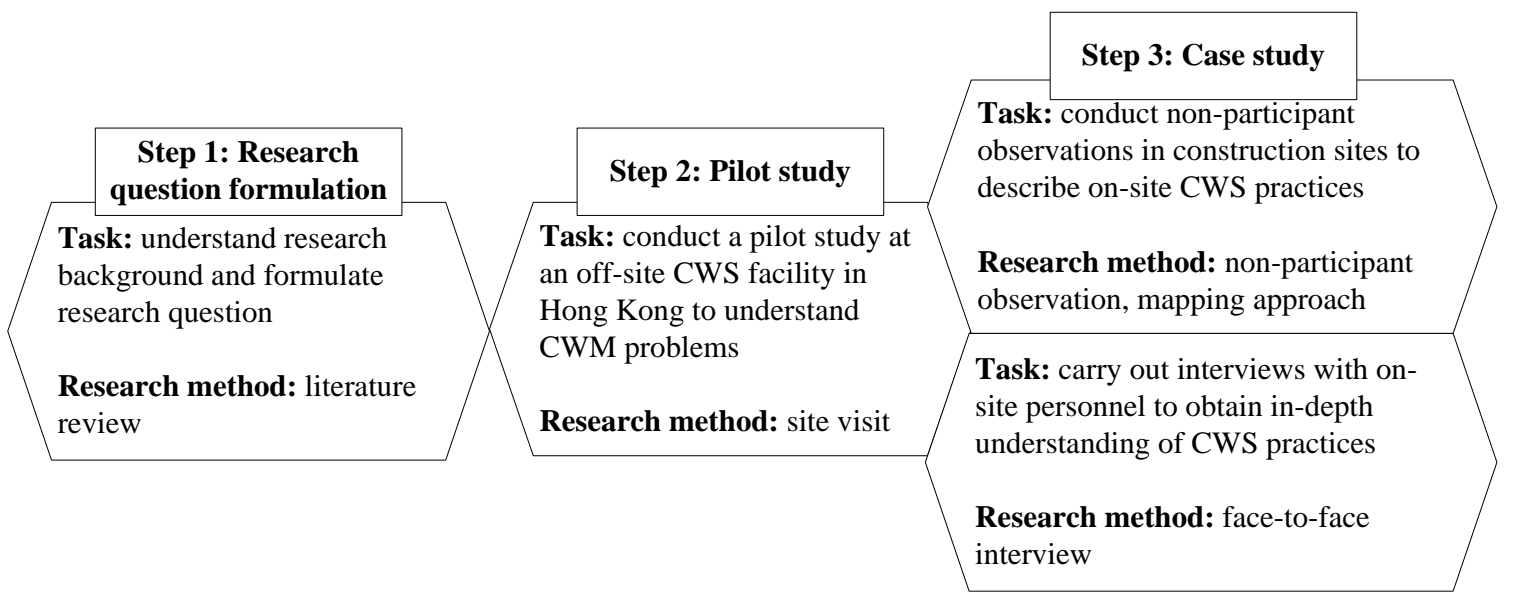

Figure 1: The research methodology adopted in the study 


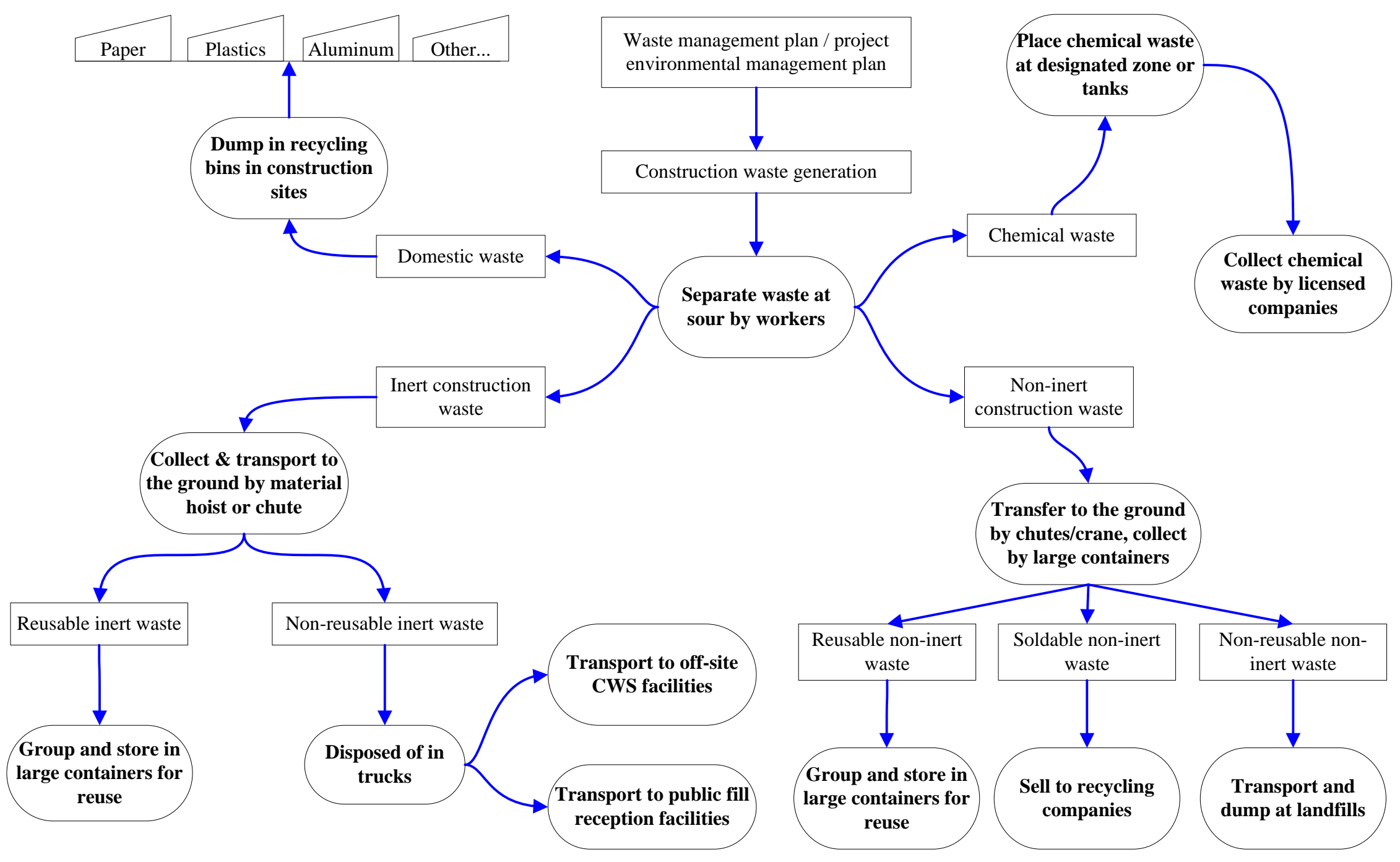

Figure 2: The on-site construction waste sorting processes in the studied cases 


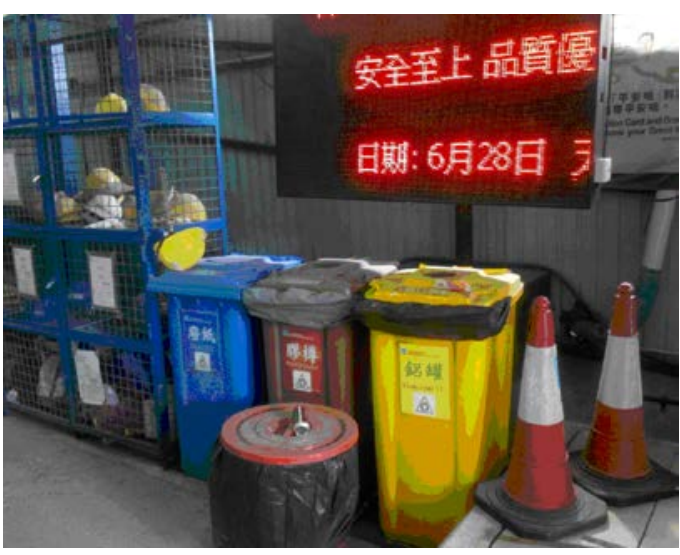

$\mathrm{a}$

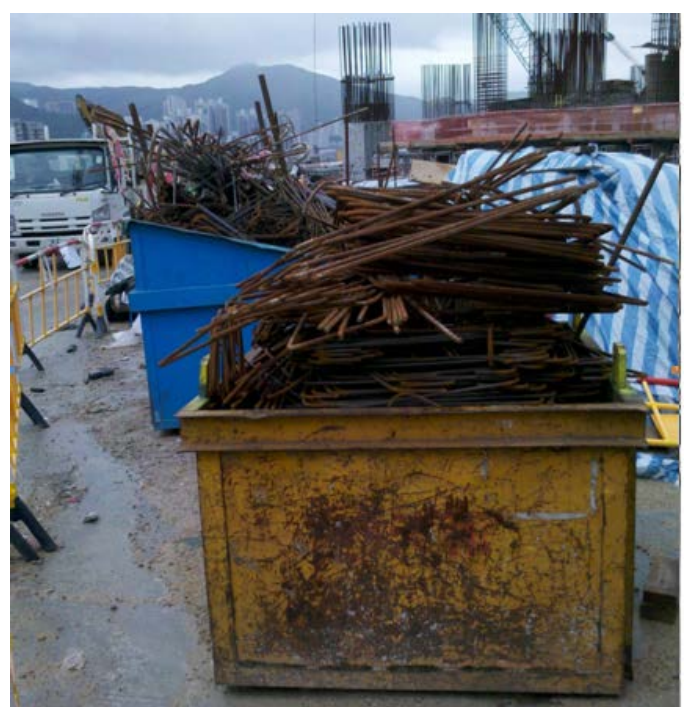

C

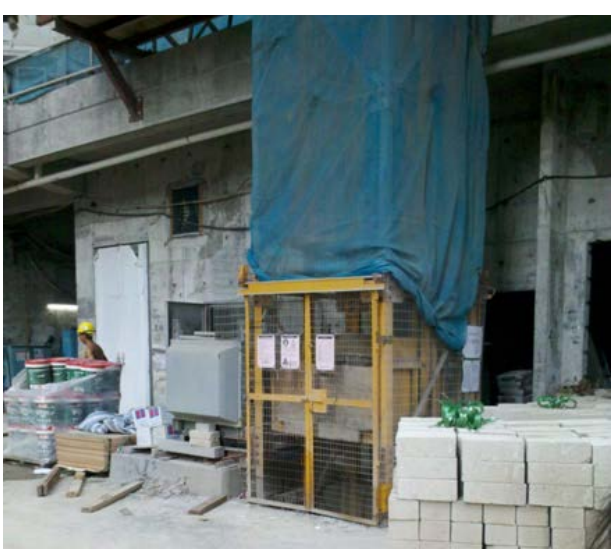

b

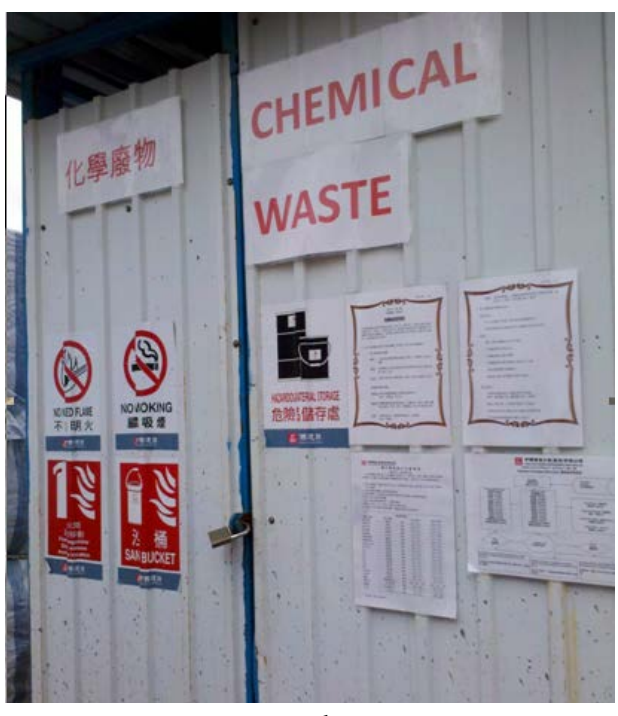

d

Figure 3: some typical scenarios of on-site CWS 


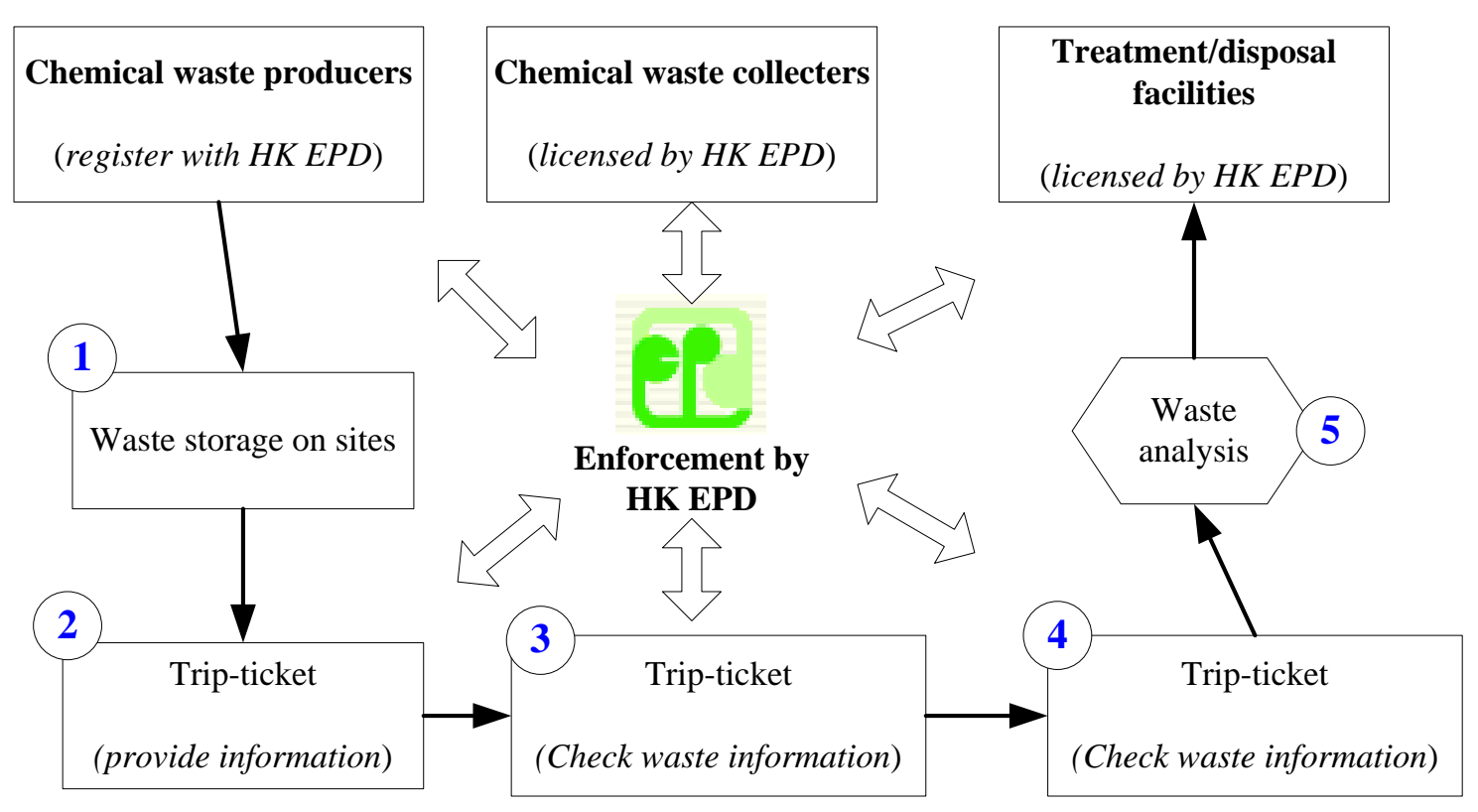

Figure 4: 'Generation to disposal' of chemical waste in construction projects (Source: Drawn based on (HKEPD), 2012) 
Table 1: Profile of the surveyed construction projects

\begin{tabular}{|c|c|c|c|c|c|c|}
\hline $\begin{array}{l}\text { Project } \\
\text { No. } \\
\end{array}$ & Project type & $\begin{array}{c}\text { Contract } \\
\text { sum }\end{array}$ & Interviewee & $\begin{array}{c}\text { Interviewee's } \\
\text { experience }\end{array}$ & $\begin{array}{l}\text { Main construction } \\
\text { waste components }\end{array}$ & $\begin{array}{l}\text { Date of } \\
\text { survey }\end{array}$ \\
\hline A & Infrastructure & $\begin{array}{l}\text { HK\$28105 } \\
\text { million }\end{array}$ & $\begin{array}{c}\text { Environmental } \\
\text { officer }\end{array}$ & 7 years & $\begin{array}{l}\text { Stone, steel and } \\
\text { domestic waste }\end{array}$ & $\begin{array}{l}18 \text { May } \\
2012\end{array}$ \\
\hline B & $\begin{array}{l}\text { New private } \\
\text { building }\end{array}$ & 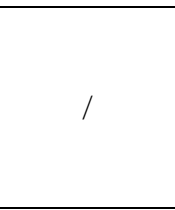 & $\begin{array}{l}\text { Safety } \\
\text { manager }\end{array}$ & 3 years & $\begin{array}{l}\text { Crushed stone, soil, } \\
\text { wood, metal, } \\
\text { plastic, chemical } \\
\text { waste and domestic } \\
\text { waste } \\
\end{array}$ & $\begin{array}{l}15 \text { June } \\
2012\end{array}$ \\
\hline $\mathrm{C}$ & $\begin{array}{l}\text { New public } \\
\text { building }\end{array}$ & $\begin{array}{c}\text { HK\$146.3 } \\
\text { million }\end{array}$ & $\begin{array}{l}\text { Environmental } \\
\text { officer }\end{array}$ & I & $\begin{array}{c}\text { Concrete scraps, } \\
\text { sand, soil, bricks, } \\
\text { metal, plastic, } \\
\text { wood, bamboo, } \\
\text { chemical and } \\
\text { domestic waste } \\
\end{array}$ & $\begin{array}{l}16 \text { June } \\
2012\end{array}$ \\
\hline $\mathrm{D}$ & $\begin{array}{l}\text { New public } \\
\text { building }\end{array}$ & $\begin{array}{l}\text { HK\$1.3 } \\
\text { billion }\end{array}$ & $\begin{array}{l}\text { Safety } \\
\text { manager }\end{array}$ & 10 years & $\begin{array}{l}\text { Concrete, soil, } \\
\text { bricks, metal, } \\
\text { plastic, wood, } \\
\text { chemical and } \\
\text { domestic waste }\end{array}$ & $\begin{array}{l}19 \text { June } \\
2012\end{array}$ \\
\hline E & $\begin{array}{l}\text { New public } \\
\text { building }\end{array}$ & $\begin{array}{c}\text { HK\$436.7 } \\
\text { million }\end{array}$ & $\begin{array}{l}\text { Safety } \\
\text { manager }\end{array}$ & 6 years & $\begin{array}{c}\text { Concrete, rock, } \\
\text { bricks, metallic } \\
\text { waste, paper, } \\
\text { plastic bottle, } \\
\text { aluminum, } \\
\text { chemical and } \\
\text { domestic waste }\end{array}$ & $\begin{array}{l}29 \text { June } \\
2012\end{array}$ \\
\hline $\mathrm{F}$ & $\begin{array}{l}\text { New public } \\
\text { building }\end{array}$ & $\begin{array}{c}\text { HK\$158 } \\
\text { million }\end{array}$ & $\begin{array}{l}\text { Safety } \\
\text { manager }\end{array}$ & 6 years & $\begin{array}{c}\text { Concrete, bricks, } \\
\text { metal, paper, } \\
\text { plastic, chemical } \\
\text { and domestic waste }\end{array}$ & $\begin{array}{l}30 \text { June } \\
2012\end{array}$ \\
\hline
\end{tabular}


Table 2: A comparison of major weaknesses in on-site CWM

\begin{tabular}{|l|c|l|l|}
\hline \multicolumn{1}{|c|}{ Major weaknesses } & $\begin{array}{c}\text { Shen et al. } \\
\text { (2004) }\end{array}$ & Case study & \multicolumn{1}{|c|}{ Evidence of improvement } \\
\hline $\begin{array}{l}\text { W1: lack of waste sorting-out } \\
\text { process }\end{array}$ & Strong & Insignificant & $\begin{array}{l}\text { Waste source separation is } \\
\text { implemented }\end{array}$ \\
\hline $\begin{array}{l}\text { W2: no consideration for } \\
\text { recycling waste }\end{array}$ & Strong & Insignificant & $\begin{array}{l}\text { Waste recycling is well } \\
\text { considered }\end{array}$ \\
\hline $\begin{array}{l}\text { W3: intensive labor work } \\
\text { involved in handling waste }\end{array}$ & Strong & Insignificant & $\begin{array}{l}\text { Few workload for handling } \\
\text { waste generated }\end{array}$ \\
\hline $\begin{array}{l}\text { W4: double-handling in } \\
\text { collecting waste }\end{array}$ & Strong & Insignificant & $\begin{array}{l}\text { Waste containers are placed on- } \\
\text { site both for inert and non-inert } \\
\text { waste }\end{array}$ \\
\hline $\begin{array}{l}\text { W5: time consumed for collecting } \\
\text { waste from scattered collection } \\
\text { locations }\end{array}$ & Strong & Insignificant & $\begin{array}{l}\text { Different types of waste are } \\
\text { stored in designated site areas }\end{array}$ \\
\hline
\end{tabular}


Table 3: A comparison of factors affecting on-site CWS practices in Hong Kong

\begin{tabular}{|c|c|c|c|c|c|c|c|}
\hline Factors & $\begin{array}{c}\text { Poon et al. } \\
\text { (2001) }\end{array}$ & Project A & Project B & Project C & Project D & Project E & Project F \\
\hline F1 & $* * *$ & $* * *$ & $* * *$ & $* * *$ & $* * *$ & $* * *$ & $* * *$ \\
\hline F2 & $* * *$ & $* * *$ & $* * *$ & $*$ & $* * *$ & $* * *$ & $* * *$ \\
\hline F3 & $* * *$ & $*$ & $*$ & $*$ & $* * *$ & $*$ & $* * *$ \\
\hline F4 & $* * *$ & $* * *$ & $* * *$ & $* * *$ & $* * *$ & $* * *$ & $*$ \\
\hline $\mathrm{F5}$ & $*$ & $* * *$ & $* * *$ & $*$ & $*$ & $* * *$ & $*$ \\
\hline F6 & $*$ & $*$ & $* * *$ & $* * *$ & $* * *$ & $*$ & $* * *$ \\
\hline F7 & $* * *$ & $* * *$ & $* * *$ & $* * *$ & $* * *$ & $* * *$ & $* * *$ \\
\hline
\end{tabular}

Note: F1-site space, F2-management effort, F3-labor and cost, F4-interference with normal site activities, F5-waste sortability, F6-market for recyclables and environmental benefit, and F7-project stakeholders' attitudes toward implementing on-site CWS. *** indicates the factor has major influence on on-site CWS of the corresponding project, while * means that the factor has minor impact on on-site CWS of the corresponding project. 